\title{
Synthesis and Characterization of Vinyl Acetate Grafted onto Industrial Cellulose
}

\section{Chiagozie Michael Ekwunife*, Vincent Ishmael Egbulefu Ajiwe, Collins Chibuzor Odidika, Uchenna Emmanuel Amalu}

Department of Pure and Industrial Chemistry, Nnamdi Azikiwe University, Awka, Nigeria

Email address:

cm.ekwunife@unizik.edu.ng (C. M. Ekwunife)

${ }^{*}$ Corresponding author

\section{To cite this article:}

Chiagozie Michael Ekwunife, Vincent Ishmael Egbulefu Ajiwe, Collins Chibuzor Odidika, Uchenna Emmanuel Amalu. Synthesis and Characterization of Vinyl Acetate Grafted onto Industrial Cellulose. Science Journal of Chemistry. Vol. 8, No. 3, 2020, pp. 66-71. doi: $10.11648 /$ j.sjc.20200803.14

Received: May 21, 2020; Accepted: June 8, 2020; Published: June 23, 2020

\begin{abstract}
This study was aimed at investigating the synthesis and characterization of vinyl acetate grafted on Industrial Cellulose. Vinyl acetate monomer was grafted onto Industrial cellulose using benzoyl peroxide as initiator at varied temperatures. The Industrial cellulose-g-poly(vinyl acetate) was orange in colour. The effect of initiator concentration, monomer concentration and temperature on percentage grafting and grafting efficiency of the product was determined. Both percentage grafting and grafting efficiency increased with initiator concentration and monomer concentration for the industrial cellulose-g-poly(vinyl acetate). The percentage grafting and grafting efficiency increased with temperature from $60^{\circ} \mathrm{C}-70^{\circ} \mathrm{C}$ then decreased after $70^{\circ} \mathrm{C}$ for the sample. The graft copolymer was analyzed and characterized using various tests, which included Fourier transformed infrared spectrophotometer, physico-mechanical tests which were, hardness test with durometer shore hardness tester, density with Monsanto Densitron 2000, softening point tester with HDT/Vicat Test Station. Moreover, adsorption studies of bromothymol blue onto the sample was done with Ultraviolet-visible spectrophotometer. The results of the FTIR confirmed the presence of O-H of alcohol $\left(3404 \mathrm{~cm}^{-1}\right), \mathrm{C}=\mathrm{O}$ of esters $\left(1645 \mathrm{~cm}^{-1}\right), \mathrm{N}-\mathrm{H}$ of protein $\left(2272 \mathrm{~cm}^{-1}\right), \mathrm{C}-\mathrm{H}$ of methyl and methylene $\left(2933 \mathrm{~cm}^{-1}\right)$, and C-O of esters $\left(1122 \mathrm{~cm}^{-1}\right)$ in the Industrial cellulose-g-poly(vinyl acetate). The result of the hardness showed that the Industrial cellulose-g-poly(vinyl acetate) was $87 \mathrm{D}$, the density was $0.95 \mathrm{mg} / \mathrm{m}^{3}$, and the softening point was $115^{\circ} \mathrm{C}-135^{\circ} \mathrm{C}$. The percentage of bromothymol blue removed from aqueous solution was $72.4 \%$ for industrial cellulose-g-poly(vinyl acetate). The rate constants for the Industrial graft copolymer was determined using pseudo first order kinetics and it gave $3.59 \times 10^{-2} \mathrm{~min}^{-1}$. The research showed that Industrial cellulose-g-poly(Vinyl acetate) could be used in the adsorption of bromothymol blue (dye) in aqueous solution.
\end{abstract}

Keyword: Industrial Cellulose-g-Poly(Vinyl Acetate), Industrial Cellulose, Graft Copolymer

\section{Introduction}

Cellulose is the most abundant renewable raw material in the world. It sources ranges from small amount found in lower classes of animals such as tunicates in bacteria, muscular tissues of certain mammals and in the cell walls of trees where it is the major constituent and to cotton where it occurs in a pure form. The molecular structure of cellulose is a linear syndiotactic homo-polymer that consist of DAnhydroglucopyranose units, called AGU i.e. it is a homopolymer of glucose. These units are linked together by $\beta$
$(1 \rightarrow 4)$ - glycosidic bonds and the chains are arranged in one plane. It is a carbohydrate composed of carbon $(49.39 \%)$, oxygen (44.4\%) and Hydrogen (6.17\%).

Grafting with vinyl acetate (monomer) is an effective method of modifying the properties of cellulosic materials. Since cellulose is not soluble in some organic solvents and modification is attained when grafting in a heterogeneous medium. When using a single monomer, the grafting usually occurs in a single step, but when grafting binary monomer 
mixture, the reaction is carried out with the use of two monomers at the same time or one after the other [1]. After grafting with monomer (vinyl acetate) onto linear chained cellulose backbone, a branched cellulose copolymer is obtained. The physical and mechanical properties of the cellulose graft copolymer depends on the kind and amount of monomer grafted onto the cellulose. After grafting reaction has taken place in heterogeneous medium, purification is achieved by completely removing the homo-polymer from the grafting mixture by extraction with a suitable solvent.

However, in the case of homogeneous grafting, the graft copolymer is purified by precipitation and is characterized by some parameters such as grafting percentage (GP\%), and grafting efficiency (GE\%) [5]. The type of initiator used for grafting has an important effect because it determines the grafting percentage depending on the monomer to be used for grafting. In grafting with vinyl monomers onto cellulose, the initiation can be performed by chemical initiators. When binary mixture of acrylonitrile and methylacrylate was grafted onto cellulosic fibers in the presence of Ce(IV)ions, it was noticed that the grafting changed substantially on varying the co-monomers concentration [3]. In order to obtain a cellulose graft copolymer with high water or moisture absorbency, hydrophilic monomers such as acrylic acid (AA), acrylamide (AAm), 2-acrylamidomethylpropane sulfonic acid $\left(\mathrm{AASO}_{3} \mathrm{H}\right)$, etc. should be grafted onto the cellulose. In order to improve the compatibility and adhesion of hydrophilic cellulose fibers to the components of hydrophobic composites, hydrophobic monomers such as methyl methacrylate, styrene, acrylonitrile, butadiene, isobutyl vinyl ether, and vinyl acetate should be grafted onto the surface of cellulose [8]. Graft copolymerization is a common method used for the amendment of polymers [6] in the sense that it modifies the physical and chemical properties of polymers. The side chains are covalently bonded to the main polymer backbone during grafting to form a copolymer with branched structure.

\section{Materials and Methods}

\subsection{Preparation of Graft Copolymer of Vinyl Acetate onto Industrial Cellulose}

Cellulose $(2.5 \mathrm{~g})$ was dispersed in $50 \mathrm{~mL}$ of distilled water. The substrate was initiated with $2 \pm 0.5 \mathrm{~g}$ of benzoyl peroxide and stirred for 5 minutes. After initiation, about $20 \pm 10 \mathrm{~mL}$ of 40 moles of vinyl acetate was added to the reaction flask and monitored with continuous stirring. The reaction mixture was heated up using the laboratory hot plate at various temperature ranging from $60^{\circ} \mathrm{C}-80^{\circ} \mathrm{C}$ and stirred continuously for $30 \mathrm{mins}$ of reaction time. After the completion of the reaction, the rough products were first precipitated in an excess of acetone and then separated by filtration. To obtain the pure graft copolymer, carbon-tetrachloride was used to extract the homopolymer that might be produced during the polymerization. Extracting for $6 \mathrm{~h}$ was sufficient to remove the polyvinyl acetate homo-polymer.

\subsubsection{Grafting Percentage}

The grafting percentage (GP) indicates the increase in weight of original cellulose subjected to grafting with a monomer and it is calculated generally from the following equation:

$$
\mathrm{GP}=\frac{\text { Weight of polymer Grafted }}{\text { Initial Weight of Backbone }} \times 100=\frac{\mathrm{W}_{1}-\mathrm{W}_{0}}{\mathrm{~W}_{0}} \times 100
$$

Where $\mathrm{W}_{1}$ and $\mathrm{W}_{0}$ are the weights of the cellulose graft copolymer and the original cellulose, respectively.

\subsubsection{Grafting Efficiency}

Grafting efficiency (GE) shows the fraction of monomer grafted onto cellulose and the amount of monomer converted to graft polymer plus the homo-polymer, in other words, fraction of polymer that is grafted to cellulose in total polymer, and it is calculated from the equation (2):

$$
\begin{gathered}
=\frac{\text { Weight of Polymer Grafted }}{\text { Weight of Polymer Grafted + Weight of Homopolymer }} \times 100 \\
=\frac{\mathrm{W}_{1}-\mathrm{W}_{0}}{\left(\mathrm{~W}_{1}-\mathrm{W}_{0}\right) /\left(\mathrm{W}_{1}-\mathrm{W}_{0}+\mathrm{W}_{2}\right)} \times 100
\end{gathered}
$$

While the $\mathrm{W}$ represents weight of original cellulose $\left(\mathrm{W}_{0}\right)$, cellulose graft copolymer $\left(\mathrm{W}_{1}\right)$ and the homo-polymer $\left(\mathrm{W}_{2}\right)$.

\subsection{Physico-mechanical Properties Test}

In the physico-mechanical tests, the hardness test was carried out using the Durometer shore hardness tester ASTM D1415/ISO 48. The model of density instrument used was Monsanto Densitron 2000. The softening point was tested using the Vicat station equipment HDT/Vicat tester and it was taken at the temperature when the indenter reached the base of the specimen.

\subsection{Sorption Behaviour of Industrial Cellulose-g-Poly(Vinyl Acetate)}

The cellulose-g-poly(vinyl acetate) of industrial cellulose was immersed in various organic solvents at room temperature and monitored to detect the increase and reduction in weight of the cellulose material. The solvents used where acetone, chloroform and methanol in order of polarity. Therefore, the void size and accessible amorphous regions are supposed to be responsible for the reaction.

\subsection{Fourier Transformed Infrared Spectrophotometer}

The model of Fourier transform infrared spectrophotometer used was FTIR-8400S produced from SHIMADZU Company Japan. The test was performed to get authenticated information about the vibrational regions present in the cellulose graft copolymer of the industrial cellulose.

\subsection{Absorption of Bromothymol Blue Dye Using Industrial Cellulose-g-Poly(Vinyl Acetate)}

Bromothymol blue $(0.5 \mathrm{~g})$ was weighed out and made up 
with Analar grade ethanol to $50 \mathrm{~mL}$ using a measuring cylinder and poured into a conical flask. $2.5 \pm 0.5 \mathrm{~mL}$ each of the dye in solution was measured out and made up to $50 \mathrm{~mL}$, after which a fixed weight in grams of the cellulose beads was immersed in each flask with intermittent shaking at room temperature of $25 \pm 1^{\circ} \mathrm{C}$. The bromothymol blue $\mathrm{pH}$ was maintained at buffer 4 by adjusting them with addition of sulfuric acid $\left(\mathrm{H}_{2} \mathrm{SO}_{4}\right)$.

Thereafter, the amount of dye adsorbed was analyzed at $\kappa_{\max } 570 \mathrm{~nm}$. The initial concentration and adsorbent dosage were varied and the variation in the amount of dye taken up by the adsorbent was analyzed. In each flask, various amount of the adsorbent beads were added prior to a continuous shaking at temperature of $25 \pm 1^{\circ} \mathrm{C}$. This solution was filtered after a particular time interval and spectrophotometric analysis was performed for the amount of the dye uptake.

The amount of dye adsorbed $\left(\mathrm{q}_{\mathrm{e}}\right)$ onto the cellulose beads and the percentage of removal $(\mathrm{R})$ were calculated using equations 3 and 4 .

$$
\begin{array}{r}
q_{e}=\left(C_{0}-C_{e}\right) \frac{V}{W} \\
R=\left(\frac{C_{0}-C_{e}}{C_{0}}\right) \times 100
\end{array}
$$

Where $\mathrm{C}_{0}$ and $\mathrm{C}_{\mathrm{e}}$ are the initial and equilibrium concentration $(\mathrm{mg} / \mathrm{l})$, respectively, $\mathrm{V}$ is the volume of the solution (L) and $\mathrm{W}$ is the amount of adsorbent $(\mathrm{g})$.

\subsection{Effect of Time}

The study was done to know the amount of dye adsorbed at various time intervals by a fixed amount of the adsorbent.

\subsection{Effect of Initial Dye Concentration}

The study was done to know the concentration of dye that was adsorbed by the adsorbent at different concentrations.

\section{Result and Discussions}

\begin{tabular}{|c|c|c|c|c|c|}
\hline Preliminary test & $\begin{array}{l}\text { Initial weight of Industrial } \\
\text { cellulose (g) }\end{array}$ & $\begin{array}{l}\text { Weight of } \\
\text { initiator (g) }\end{array}$ & $\begin{array}{l}\text { Final weight of } \\
\text { Industrial cellulose (g) }\end{array}$ & $\begin{array}{l}\text { Percentage grafting } \\
(\%)\end{array}$ & $\begin{array}{l}\text { Grafting Efficiency } \\
(\%)\end{array}$ \\
\hline 1 & 2.5 & 0.5 & 6.8 & 172 & 76.0 \\
\hline 2 & 2.5 & 1.0 & 7.2 & 188 & 78.0 \\
\hline 3 & 2.5 & 1.5 & 7.5 & 200 & 79.0 \\
\hline 4 & 2.5 & 2.0 & 8.2 & 228 & 81.0 \\
\hline 5 & 2.5 & 2.5 & 8.5 & 240 & 82.0 \\
\hline
\end{tabular}

Table 1. Percentage Grafting and Grafting Efficiency of Industrial Cellulose-g-Poly(Vinyl Acetate) Versus Initiator Concentration.

\begin{tabular}{|c|c|c|c|c|c|}
\hline Preliminary test & $\begin{array}{l}\text { Initial weight of } \\
\text { Industrial cellulose (g) }\end{array}$ & $\begin{array}{l}\text { Weight of monomer } \\
(\mathrm{g})\end{array}$ & $\begin{array}{l}\text { Final weight of } \\
\text { Industrial cellulose (g) }\end{array}$ & $\begin{array}{l}\text { Percentage grafting } \\
(\%)\end{array}$ & $\begin{array}{l}\text { Grafting Efficiency } \\
(\%)\end{array}$ \\
\hline 1 & 2.5 & 10 & 6.80 & 172 & 76.0 \\
\hline 2 & 2.5 & 15 & 11.9 & 192 & 87.0 \\
\hline 3 & 2.5 & 20 & 14.0 & 198 & 89.0 \\
\hline 4 & 2.5 & 25 & 17.2 & 200 & 92.0 \\
\hline 5 & 2.5 & 30 & 19.4 & 205 & 93.0 \\
\hline
\end{tabular}

Table 2. Percentage Grafting and Grafting Efficiency of Industrial Cellulose-g-Poly(Vinyl Acetate) Versus Monomer Concentration.
In the kinetic analysis of the reaction of the pseudo first order, the amount of dye adsorbed was calculated at various time $(\mathrm{t})\left(\mathrm{q}_{\mathrm{t}}\right.$ in $\left.\mathrm{mg} / \mathrm{g}\right)$ and at equilibrium in $(\mathrm{mg} / \mathrm{g})$ as follows:

$$
\begin{gathered}
q_{t}=\frac{\left(C_{0}-C_{t}\right)}{M} V \\
q_{e}=\frac{\left(C_{o}-C_{e}\right)}{M} V \\
\mathrm{R} \%=\frac{\left(\mathrm{C}_{\mathrm{o}}-\mathrm{C}_{\mathrm{e}}\right)}{\mathrm{C}_{\mathrm{o}}} \times 100
\end{gathered}
$$

Where $\mathrm{C}_{\mathrm{o}}$ and $\mathrm{C}_{\mathrm{e}}$ are the initial and equilibrium concentrations of the dye in solution $(\mathrm{mg} / \mathrm{L}) . \mathrm{C}_{t}$ is the concentration of the dye in solution at time $(\mathrm{t})(\mathrm{mg} / \mathrm{L}), \mathrm{V}$ is the volume of the solution (L) and $\mathrm{M}$ is the mass of the adsorbent in $(\mathrm{g})$. Also the removal percentage $(\mathrm{R} \%)$ at equilibrium was calculated by the equation 7 .

In this study, kinetic investigation was carried out to monitor various experimental conditions like dye concentration, time, $\mathrm{pH}$, and temperature to measure the rate of reaction throughout the adsorption process with the goal of reaching equilibrium.

In order to determine the rate of bromothymol blue on the graft copolymer, the well-known Lagergrens pseudo first order equation was employed [9]. The values of $\log \left(\mathrm{q}_{\mathrm{e}}\right.$ $-\mathrm{q}_{\mathrm{t}}$ ) was calculated for each time interval at $30^{\circ} \mathrm{C}$ in equation (8).

$$
\log \left(q_{e}-q_{t}\right)=\log q_{e}-k \text { ads } t / 2.303
$$

Where $\mathrm{q}_{\mathrm{e}}$ and $\mathrm{q}_{\mathrm{t}}$ signifies, the amount adsorbed at equilibrium and at any time $(\mathrm{t})$. The graph of $\log \left(\mathrm{q}_{\mathrm{e}}-\mathrm{q}_{\mathrm{t}}\right)$ versus $(\mathrm{t})$ time gave a straight line and confirmed the pseudo first order rate kinetics for the adsorption process [4]. 
Table 3. Percentage Grafting and Grafting Efficiency of Industrial Cellulose-g-Poly(Vinyl Acetate) Versus Temperature.

\begin{tabular}{llllll}
\hline Preliminary test & $\begin{array}{l}\text { Initial weight of Industrial } \\
\text { cellulose graft }(\mathbf{g})\end{array}$ & $\begin{array}{l}\text { Final weight of Industrial } \\
\text { cellulose graft }(\mathbf{g})\end{array}$ & $\begin{array}{l}\text { Temperature } \\
\left({ }^{\circ} \mathbf{C}\right)\end{array}$ & $\begin{array}{l}\text { Percentage grafting } \\
(\%)\end{array}$ & $\begin{array}{l}\text { Grafting Efficiency } \\
(\%)\end{array}$ \\
\hline 1 & 2.5 & 6.8 & 60 & 172 & 76.0 \\
2 & 2.5 & 7.1 & 65 & 178 & 77.0 \\
3 & 7.3 & 70 & 192 & 78.0 \\
4 & 2.5 & 7.5 & 75 & 187 & 78.5 \\
5 & 2.5 & 7.0 & 80 & 180 & 77.0 \\
\hline
\end{tabular}

It was observed in Tables 1 and 2 that the percentage grafting and grafting efficiency increased with increase in initiator and monomer concentrations for the Industrial graft copolymer. The increase in initiator concentration may have occurred due to increment in the yield of initiator at the active site on the cellulose backbone.
The percentage grafting and grafting efficiency increased with temperature from $60^{\circ} \mathrm{C}-70^{\circ} \mathrm{C}$ then reduced after $70^{\circ} \mathrm{C}$ in Table 3. This was because of decrease in the yield of the product and the molecular weight of the graft chains. As the monomer and initiator concentrations remains constant.

Table 4. Physico-mechanical test on Industrial Cellulose-g-Poly(Vinyl Acetate).

\begin{tabular}{llll}
\hline S/N & Parameters & Units & Industrial Cellulose-g-Poly (Vinyl Acetate) \\
\hline 1 & Hardness & Shore D (D) & $87 \mathrm{D}$ \\
2 & Density & $\mathrm{mg} / \mathrm{m}^{3}$ & 0.95 \\
3 & Softening point & ${ }^{\circ} \mathrm{C}$ & $115^{\circ} \mathrm{C}-135^{\circ} \mathrm{C}$ \\
\hline
\end{tabular}

The physico-mechanical properties showed that industrial cellulose-g-poly(vinyl acetate) had a density of $0.95 \mathrm{mg} / \mathrm{m}^{3}$, and the hardness test was $87 \mathrm{D}$ (shore D), which means that the material is hard. Having a hardness with the same trend as ebonite shows that the material may have high resistant to chemical attack including chlorine and chlorine based compounds $[10,13]$. The major applications of these kind of material may be in making of bottles for storing chemicals, car gaskets, highly vulcanized water tanks, industrial pipes, tanks etc. The softening point for graft copolymer was $115^{\circ} \mathrm{C}$

\section{$-135^{\circ} \mathrm{C}$.}

In brief, it was observed that the graft copolymer has thermoplastic properties. And these basic properties may have proved its vitality in some areas, more research need to be done on how to improve the properties of this cellulose graft polymer so that the materials can be used for handling aggressive chemicals. This will justify that the material may have the capability to possess the mechanical properties required for various purposes.
FTIR ANALYSIS RESULT NATIONAL REASEARCH INSTITUTE FOR CHEMICAL TECHNOLOGY, ZARIA
Ф SHIMADZU FTIR-8400S FOURIER TRANSFORM INFRARED SPECTROPHOTOMETER

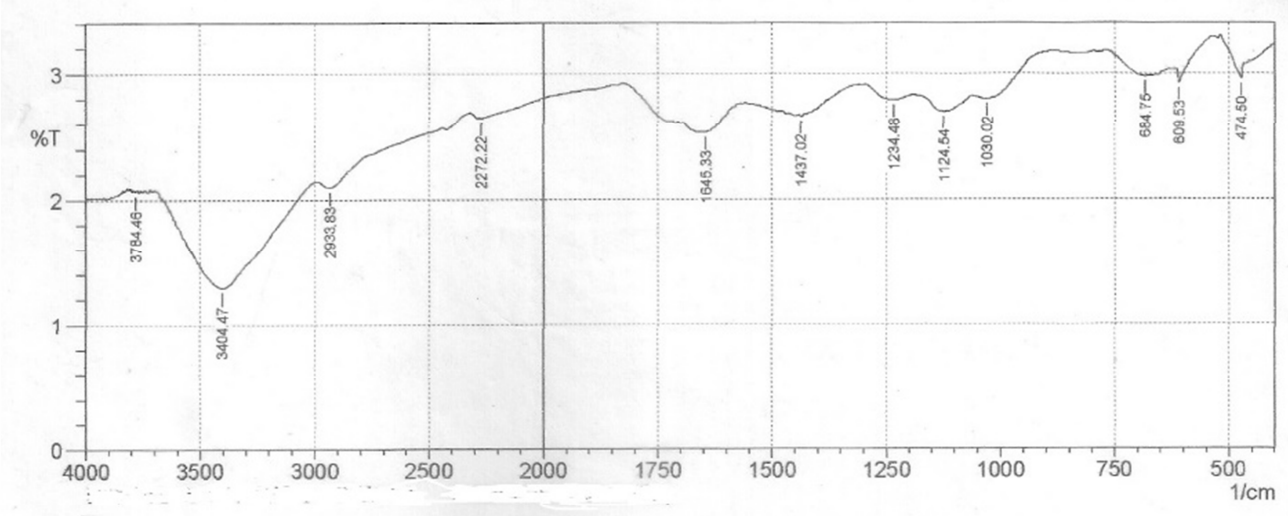

\begin{tabular}{|c|c|c|c|c|c|c|c|}
\hline & Peak & Intensity & Corr. Intensity & Base $(\mathrm{H})$ & Base (L) & Area & Corr. Area \\
\hline 1 & 474.5 & 2.9599 & 0.1555 & 518.87 & 466.79 & 78.4186 & 0.5122 \\
\hline 2 & 609.53 & 2.9261 & 0.1376 & 617.24 & 538.16 & 118.9399 & 0.3234 \\
\hline 3 & 684.75 & 2.9821 & 0.0531 & 767.69 & 659.68 & 163.7082 & 0.5144 \\
\hline 4 & 1030.02 & 2.8002 & 0.0905 & 1062.81 & 891.14 & 262.4181 & 0.8645 \\
\hline 5 & 1124.54 & 2.6976 & 0.1276 & 1193.98 & 1062.81 & 204.4317 & 1.2684 \\
\hline 6 & 1234.48 & 2.7871 & 0.0748 & 1296.21 & 1193.98 & 158.3498 & 0.7076 \\
\hline 7 & 1437.02 & 2.6614 & 0.0136 & 1442.8 & 1431.23 & 18.213 & 0.0119 \\
\hline 8 & 1645.33 & 2.5319 & 0.0203 & 1651.12 & 1585.54 & 103.7899 & 0.2153 \\
\hline 9 & 2272.22 & 2.6508 & 0.0109 & 2279.94 & 1938.52 & 533.2533 & 0.7025 \\
\hline 10 & 2933.83 & 2.0999 & 0.0917 & 2989.76 & 2440.03 & 895.1608 & -0.2665 \\
\hline 11 & 3404.47 & 1.2928 & 0.5356 & 3574.21 & 2989.76 & 1046.8891 & 42.2019 \\
\hline 12 & 3784.46 & 2.0693 & 0.0101 & 3790.25 & 3778.68 & 19.4781 & 0.0112 \\
\hline
\end{tabular}

Figure 1. FT-IR result of Industrial Cellulose-g-poly(Vinyl Acetate). 
Table 5. Sorption results of Industrial Cellulose-g-Poly(Vinyl Acetate).

\begin{tabular}{|c|c|c|c|c|}
\hline Solvents & Amount (ml) & $\begin{array}{l}\text { Industrial cellulose-g-poly(vinyl } \\
\text { acetate) initial weight (g) }\end{array}$ & $\begin{array}{l}\text { Final weight }(g) \\
\text { After immersion every } 6 \mathrm{~h}\end{array}$ & $\begin{array}{l}\text { Mean weight (g) after } \\
\text { immersion }\end{array}$ \\
\hline \multirow{4}{*}{ Acetone } & \multirow{4}{*}{$2 \mathrm{ml}$} & \multirow{4}{*}{ 管 } & 0.09 & \multirow{3}{*}{0.07} \\
\hline & & & 0.07 & \\
\hline & & & 0.06 & \\
\hline & & & Dissolved & \multirow{5}{*}{0.13} \\
\hline \multirow{4}{*}{ Chloroform } & \multirow{4}{*}{$2 \mathrm{ml}$} & \multirow{4}{*}{0.07} & 0.11 & \\
\hline & & & 0.13 & \\
\hline & & & 0.14 & \\
\hline & & & Adsorbed & \\
\hline \multirow{4}{*}{ Methanol } & \multirow{4}{*}{$2 \mathrm{ml}$} & \multirow{4}{*}{0.20} & 0.25 & \multirow{4}{*}{0.26} \\
\hline & & & 0.26 & \\
\hline & & & 0.28 & \\
\hline & & & Adsorbed & \\
\hline
\end{tabular}

After immersion for $24 \mathrm{~h}$ in three different solvents, adsorption occurred in some solvents while dissolution took place in one solvent. The industrial cellulose-g-poly(vinyl acetate) dissolved in acetone and was adsorbed in chloroform and methanol.

The infrared analysis showed the functional groups associated with $\mathrm{O}-\mathrm{H}, \mathrm{N}-\mathrm{H}, \mathrm{C}=\mathrm{O}, \mathrm{C}-\mathrm{O}, \mathrm{CH}_{2}$ of methyl and methylene which are consistent with cellulose-g-poly (vinyl acetates).

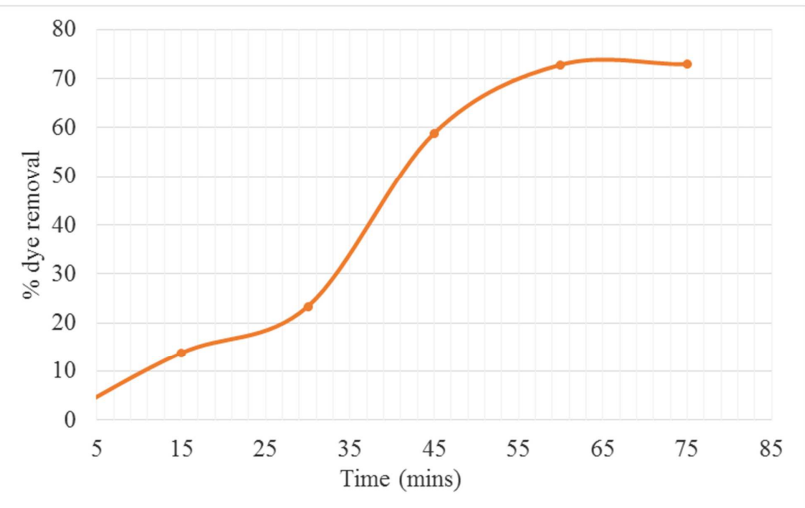

Figure 2. Plot of percentage of dye removed by the graft copolymer versus time ( $t$.

The graph in figure 2 showed the effect of time on percentage dye removal on the graft copolymer. As the time increased, more dye was removed by the Industrial celluloseg-poly(vinyl acetate). As the colour of the graft copolymer changed to green with dye removal, a chemical modification must have taken place leading to colour change in the dye [2, $12,14]$.

This is collaborated by the fact that the graft copolymer got more closely packed molecules indicating that the dye had some chemical effect on the graft copolymer.

The percentage of the dye removed by the graft copolymer increased with increase in the concentration of the dye. The concentration of the adsorbing species is linearly related to the adsorbance. The concentration of the dye was obtained from the adsorbance $[7,11,15]$.

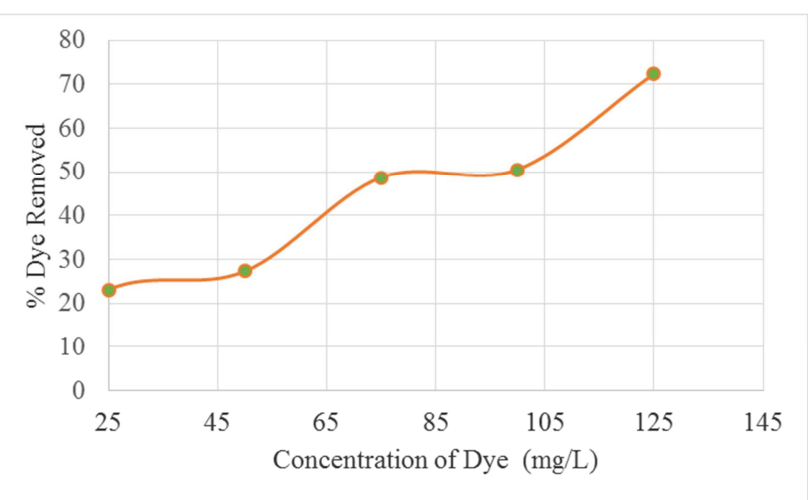

Figure 3. Plot of percentage dye removed by the graft copolymer versus Concentration of dye.

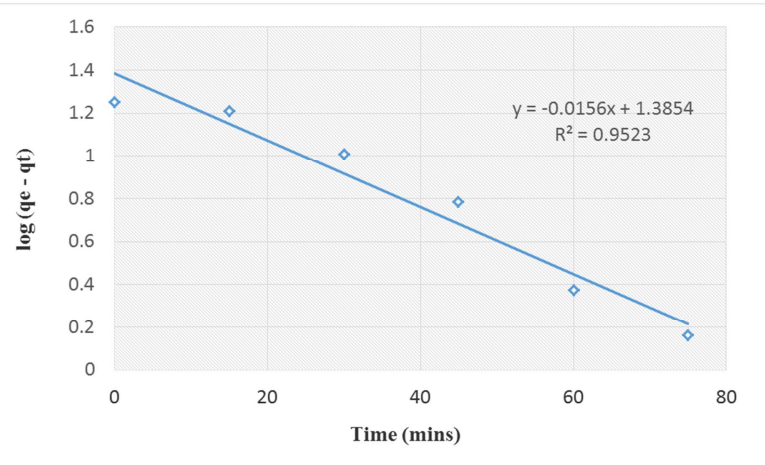

Figure 4. Plot of $\log \left(q_{e}-q_{t}\right)$ versus time (t) for Industrial cellulose.

The graph plotted between $\log \left(\mathrm{q}_{\mathrm{t}}-\mathrm{q}_{\mathrm{e}}\right)$ against time shows the change of the value of the graph rate constant $\left(\mathrm{k}_{1}\right)$. The pseudo first order equation was used in the adsorption of bromothymol blue by the graft copolymer. The rate constant was determined from the slope of the graph and was found to be $3.59 \times 10^{-2} \mathrm{~min}^{-1}$ at $30^{\circ} \mathrm{C}$. The $\left(\mathrm{R}^{2}\right)$ values was 0.952 that indicated the adsorption was reasonably good.

\section{Conclusion}

In this research, the grafting of Industrial cellulose was achieved using different quantities of vinyl acetate and 
benzoyl peroxide at different temperatures and the outcome was a graft copolymer of Industrial cellulose-g-poly (vinyl acetate).

The physico-mechanical test results of the graft copolymer from this study showed that the Industrial cellulose-g-poly (vinyl acetate) gave ( $87 \mathrm{D}$ i.e. 87 shore $\mathrm{D}$ ) for hardness, 0.95 $\mathrm{mg} / \mathrm{m}^{3}$ for density and $115^{\circ} \mathrm{C}-135^{\circ} \mathrm{C}$ for softening point.

In the adsorption of dye, it revealed that the removal of dye by the graft copolymer increased with increase in the concentration of the dye. The adsorption capacities of the graft copolymer had a removal efficiency of $72.4 \%$.

It was also observed that the percentage grafting and grafting efficiency increased with increasing initiator concentration due to the formation of great number of grafting site on the cellulose which in the presence of monomer induced grafting. Increase in temperature had a very strong effect on percentage grafting. The percentage grafting improved from $60^{\circ} \mathrm{C}$ to $70^{\circ} \mathrm{C}$ and then decreased after $70^{\circ} \mathrm{C}$.

The infrared analysis showed that the groups in the Industry cellulose-g-poly (vinyl acetate) functional groups are associated with $\mathrm{O}-\mathrm{H}, \mathrm{N}-\mathrm{H}, \mathrm{C}=\mathrm{O}, \mathrm{C}-\mathrm{O}, \mathrm{CH}_{2}$ of methyl and methylene which are consistent with graft copolymer.

\section{References}

[1] Bhattacharya, A., Misra, B. N. (2004). Grafting: a versatile means to modify polymers techniques, factors and applications. Program Polymer Science, 29: 767-814.

[2] Gómez, V., Larrechi, M., Callao M. (2007). Kinetic and adsorption study of acid dye removal using activated carbon, Chemosphere, 69: 1151-1158.

[3] Gupta, K. C., Sahoo, S., and Khandekar, K. (2002). Graft copolymerization of ethyl acrylate onto cellulose using ceric ammonium nitrate as initiator in aqueous medium. Biomacromolecules, 3 (5): 1087-1094.

[4] Gurgel, L. V. A., Junior, O. K., Gil L. F. (2008). Adsorption of $\mathrm{Cu}(\mathrm{II}), \mathrm{Cd}(\mathrm{II})$, and $\mathrm{Pb}(\mathrm{II})$ From aqueous single metal solutions by cellulose and mercerized cellulose chemically Modified with succinic anhydride. Bio-resources Technology, 99: 30773083 .

[5] Ibrahim, M. M., Flefel, E. M., El-Zawawy, W. K. (2002).
Cellulose membranes grafted with vinyl Monomers in a homogeneous system. Polymer Advance Technology, 13: 548-557.

[6] Othmer, K. (2004). Encyclopedia of Chemical Technology, 4thed. Wiley and Sons Inc, New York, 5: 236-246.

[7] Patil, S., Renukdas, S., Patel, N. (2012). Kinetic and thermodynamic study of removal of Ni (II) ions from aqueous solutions using low cost adsorbents. International journal of environmental sciences, 3 (1): 322-326.

[8] Roy, D., Guthrie, J. T., Perrier, S. (2005). Graft polymerization: grafting poly(styrene) from cellulose via reversible addition-fragmentation chain transfer (RAFT) polymerization. Macromolecules, 38: 10363-10372.

[9] Singh, J, Kaur, R, Khare, R. (2013). Batch Sorption Dynamics, Kinetics and equilibrium studies of $\mathrm{Cr}(\mathrm{IV}), \mathrm{Ni}(\mathrm{II})$ and $\mathrm{Cu}(\mathrm{II})$ from aqueous phase using agricultural residues. Applied Water science, 3 (1): 207.

[10] Singha, A. S., Rana, A. K. (2012). Effect of surface modification of Grewia optiva fibres on their physicochemical and thermal properties. Journal Material Science, 35: 1099-1110.

[11] Liu, L., Liao, Q., Xie, J., Qian, Z., Zhu, W., Chen, X., Su, X., Meng, R., Yao, J. (2016). Synthetic control of three dimensional porous cellulose - based bio-adsorbents: Correlation between structural feature and metal ion removal capability. Cellulose, 23: 3819-3835.

[12] Ren, H. X., Gao, Z. M., Wu, D. J., Jiang, J. H., Sun, Y. M., Luo, C. W. (2016). Efficient $\mathrm{Pb}$ (II) removal using sodium alginate - carboxymethyl cellulose gel beads: Preparation, characterization, and adsorption mechanism. Carbohydrate Polymer, 137: 402-409

[13] Yadav, M., Chiu, F. C. (2019). Cellulose nanocrystals reinforced $\kappa$ carrageenan based UV resistant transparent bionanocomposite films for sustainable packaging applications. Carbohydrate Polymer, 211: 181-194.

[14] Liu, S., Zhang, Y., Jiang, H., Wang, X., Zhang, T., Yao, Y. (2018). High $\mathrm{CO}_{2}$ adsorption by amino-modified bio-spherical cel-lulose nanofibres aerogels. Environmental Chemistry Letters, 16: 605-614

[15] Zhang, M., Li, Y., Yang, Q. L., Huang, L. L., Chen, L. H., Ni, Y. H., Xiao, H. N. (2018). Temperature and $\mathrm{pH}$ responsive cellulose filament/poly(NIPAM - coAAc) hybrids as novel adsorbent towards $\mathrm{Pb}(\mathrm{II})$ removal. Carbohydrate Polymer, 195: 495-504. 